PROCEDIA

Studi Kasus dan Intervensi Psikologi

ISSN:2302-1462

Volume 8(1) 19-25, Maret 2020

DOI: $10.22219 /$ procedia.v4i1.11963

\title{
Reality Therapy untuk meningkatkan self acceptance pada mahasiswa dengan problem kecemasan
}

Annisa Baitina, Universitas Muhammadiyah Malang, Malang, Indonesia

Korespondonesi:

Annisa Baitina, Universitas Muhammadiyah Malang, e-mail:annisabaitina9@gmail.com

\begin{abstract}
Riwayat artikel
Naskah diterima:

$07 / 11 / 2019$

Revisi diterima:

$30 / 01 / 2020$

Naskah disetujui:

$02 / 03 / 2020$

Abstrak

Penerimaan diri merupakan masalah yang sering terjadi pada individu yang mengalami kecemasan. Studi kasus ini bertujuan untuk meningkatkan self acceptance pada mahasiswa dengan problem kecemasan. Asesmen dilakukan untuk mendiagnosa subjek adalah wawancara, observasi, dan tes psikologi yang meliputi tes grafis, SPM, dan Self Acceptance Scale. Hasil asesmen awal menunjukkan bahwa individu ingin memiliki teman yang banyak dan tidak lagi cemas ketika presentasi di kelas. Intervensi dilakukan untuk meningkatkan self acceptance yang ditandai dengan kesadaran diri bahwa dia memiliki kelebihan dan kemampuan untuk sama dengan teman-temannya, dan dapat memahami materi kuliah dengan baik. Intervesi Reality therapy yang diikuti subjek menghasilkan peribahan pada subjek, yaitu mampu mengetahui kelebihan dan kekurangannya, dapat menyusun jangka pendek dan jangka panjang, serta menyusun langkah-langkah mewujudkannya.

Kata kunci: reality therapy, self acceptance, kecemasan, problem dewasa, perencanaan.
\end{abstract}

\section{Latar Belakang}

Kecemasan merupakan suatu keadaan yang terjadi ketika individu mengalami kekhawatiran yang berlebihan terhadap suatu kejadian atau situasi tertentu. Hal ini terjadi ketika intensitas, durasi, dan frekuensi kegelisahan atau kekhawatiran tidak sesuai dengan keadaan sebenarnya dan hal tersebut tidak dapat diantasipasi oleh indivudu tersebut yang menjadikan kekhawatiran tersebut tak terkendali (APA, 2013). Kecemasan mungkin tidak akan muncul setiap saat, mungkin muncul ketika ada stimulus atau simptom yang membuat rasa cemas tidak dapat terkendali sehingga berakibat yang lebih parah dan mengarah ke gangguan kecemasan (Nutt, Griez, Faravelli, Zohar, \& Wiley, 2001). Subjek IFT mengalami kecemasan ketika sedang dalam proses kuliah karena menurutnya subjek tidak bisa mengikuti perkuliahan dengan baik. Subjek berpikir bahwa dirinya salah memilih jurusan yang membuatnya tidak maksimal dalam mengikuti perkuliahan. 
Penerimaan diri (self acceptance) merupakan suatu penerimaan terhadap keadaan diri sendiri atau suatu kondisi dimana individu mampu menghadapi tekanan psikologis dan mampu menyesuaiakn diri dengan baik sehingga muncul kesejahteraan bagi dirinya (Vasile, 2013). Salah satu aspek penting dari penerimaan diri adalah kemampuan dan kemauan untuk membiarkan bagaimana orang melihat diri kita. Selain itu, seseorang dengan penerimaan diri yang baik berarti dapat menjalani hidup tanpa khawatir bahwa orang lain akan menghakimi atau melihat diri mereka negatif (Carson \& Langer, 2014). Seseorang dengan penerimaan diri rendah biasanya tidak akan mampu mengenali kemampuan diri mereka sendiri dan mereka akan cenderung memilih untuk menutup diri, hidup dalam kepura-puraan dan mereka akan menikmati hal tersebut karena dengan melakukan hal itu, mereka akan terhindar hari pandangan negatif orang lain (Carson \& Langer, 2014).

Untuk meningkatkan self acceptance pada subjek dilakukan dengan reality therapy. Pada penelitian sebelumya diketahui reality therapy dinilai cukup efektif untuk membangun kepercayaan diri seseorang agar mengatahui kelebihan dan kemampaun dirinya sendiri, selain itu reality therapy juga dapat membuat subjek berpikir lebih terarah mengenai rencana untuk masa depan (Younesi, Khazan, Jani, \& Mahdizadeh, 2017; Farahanifar, 2016).

\section{Metode Asesmen}

Metode asesmen yang digunakan adalah observasi, wawancara, dan tes psikologi. Wawancara dilakukan terhadap subjek dan teman kuliah subjek dengan tujuan untuk memperoleh informasi secara mendalam yang berkaitan dengan permasalahan subjek secara keseluruhan. Observasi dilakukan untuk pemeriksaan status mental yang meliputi penampilan subjek, perilaku, dan kesadaran subjek.

Tes psikologis yang digunakan mencakup tes kepribadian yaitu tes grafis (BAUM, DAP, dan HTP), SPM, dan self acceptance scale. Tes grafis diperlukan untuk mengetahui kepribadian subjek secara lebih mendalam. Standard Progressive Matrices (SPM) digunakan untuk mengetahui grade intelektual subjek, dan self acceptence scale untuk mengetahui sejauh mana subjek memiliki penerimaan diri.

\section{Presentasi Kasus}

Subjek (perempuan/20 tahun) merupakan anak pertama dari tiga bersaudara. Saat ini subjek masih menempuh pendidikan di salah satu perguruan tinggi dan mengambil jurusan peternakan, saat ini masih berada di semester 6. Subjek memiliki satu adik perempuan dan laki-laki yang masih duduk di bangku sekolah. Ayah dan ibu subjek sama-sama bekerja sebagai Pegawai Negeri Sipil (PNS) di salah satu kantor pemerintahan di Jawa Timur.

Subjek merasa salah memlih jurusan karena yang subjek inginkan adalah masuk kedokteran, namun karena ayahnya memaksa masuk peternakan akhirnya subjek pun menyetujuinya. Namun, dalam perjalanannya subjek mengalami banyak kesulitan subjek merasa tidak mampu dalam perkuliahan. Menurut subjek nilainya tidak pernah bagus dan subjek kesulitan dalam menerima pelajaran di kelas. Subjek merasa hingga saat ini tidak terlalu paham dengan apa yang menjadi hal penting yang harus dipelajari di kelas. Subjek menjadi putus asa dan terkadang tidak ingin melakukan apapun dan hanya ingin tidur.

Subjek merasa tidak mengetahui apa yang menjadi keahlian dirinya karena sejak kecil ayahnya sudah mengarahkan subjek ketika akan melakukan sesuatu, hingga kuliah pun ayah subjek yang memilihkan. Subjek sebenarnya tidak menyetujui pilihan ayahnya namnun subjek tidak dapat menolaknya. Begitu pula dengan adik-adik subjek juga diperlakukan sama oleh ayah subjek. Hubungan subjek dengan adik-adiknya cukup baik, subjek dan adiknya sering pergi bersama dan sering bercerita tentang keseharian atau hal lainnya. Menurut subjek di rumah dirinya lebih dekat dengan ibunya, karena ibunya yang dapat mendengarkan cerita subjek dan 
mampu memberikan solusi yang baik untuk subjek walaupun ibu subjek tidak dapat membantu subjek jika ayahnya mulai mengatur subjek namun ibunya selalu memberikan semangat untuk subjek.

Dalam pergaulan, subjek cenderung pendiam dan sulit dalam menyesuaikan diri hal tersebut didukung dengan hasil tes grafis yang menunjukkan bahwa subjek ada hambatan dalam interaksi sosial. Subjek lebih sering menutup diri dan enggan bergaul jika tidak dengan teman-teman yang dekat dengan subjek. subjek lebih sering menyimpan permasalahan yang dirinya hadapi sendiri dan enggan menceritakan masalahnya dengan sahabatnya sekalipun karena menurut subjek dirinya tidak ingin merepotkan orang lain. Teman subjek juga mengungkapkan hal yang sama bahwa subjek adalah seseorang yang moody jika subjek sedang ingin sendiri maka teman-temannya akan memahaminya dan tidak menggangu subjek.

Subjek sampai saat ini tidak mengetahui apa kelebihan yang dirinya miliki dan tidak memiliki rencana tenatang masa depannya atau rencara untuk waktu sekarang. Subjek merasa pesimis kerena menganggap bahwa dirinya saat ini saja tidak terlalu pintar bagaiman nanti dirinya dapat mewujudkan keinginannya. Subjek merasa tidak ada yang mendukungnya dan membantunya dalam berbagai hal. Sedangkan berdasarkan tes Standar Progressive Matrices (SPM) subjek memiliki grade taraf intelektual yaitu high auto superior, yang berarti subjek memiliki pemahaman yang baik.

Dari keseluruhan hasil asesmen dapat disimpulkan bahwa subjek memiliki permasalahan pada self acceptance dimana subjek tidak percaya pada kemampuannya sendiri, tidak mnegetahui kelebihan yang dirinya miliki dan belum memiliki rencana untuk dirinya sendiri. Penerimaan diri yaitu bagaimana seseorang memandang dirinya positif dan memiliki kemampuan untuk menonjolkan kemampuannya dihadapan orang lain tanpa rasa ragu (Vasile, 2013). Self acceptance mengacu pada kepuasan individu terhadap dirinya sendiri yang melibatkan pemahaman terhadap diri sendiri, kesadaran yang realistis, mengerti akan kelebihan dan kekurangan diri sendiri maupun orang lain, serta mengetahui bahwa setiap orang akan berbeda (Shepard \& Shepard, 2015).

\section{Diagnosis dan Prognosis}

Subjek memenuhi kriteria diagnostik Other Specified Anxiety Disorder 300.09 (F41.8) dengan permasalahan rendahnya self acceptance atau penerimaan diri. Prognosis pada subjek yaitu baik, karena faktor pencetus yang jelas, rapport yang terjalin dengan baik, segera dilakukan penanganan, taraf intelegensi berdasarkan grade SPM yaitu high auto superior dan adanya motivasi subjek yang ingin menjadi lebih baik dan tidak lagi mudah putus asa dalam menghadapi permasalahan.

\section{Intervensi}

Terapi reaitas merupakan suatu sistem yang difokuskan pada tingkah laku sekarang. Terapis berfungsi sebagai guru dan model serta mengkonfrontasikan subjek dengan cara-cara yang dapat membantu subjek menghadapi kenyataan dan memenuhi kebutuhan-kebutuhan dasar tanpa merugikan diri sendiri maupun orang lain. Inti terapi realitas adalah penerimaan tanggung jawab pribadi yang disamakan dengan kesehatan mental. Terapi realitas yang menguraikan prinsi-prinsip dan prosedur yang dirancang untuk membantu orang dalam mencapai keberhasilan. Reality Therapy sebagai sistem konseling membantu orang dalam memuaskan keinginan dan kebutuhan mereka dalam mengevaluasi kebutuhan mereka menjadi suatu perilaku (Wubbolding, 2017). Terapi realitas membantu orang dalam membantu dan memperjelas tujuan-tujuan meraka. Terapis harus memiliki tujuan tertentu bagi subjek dalam pikirannya. Mereka menekankan bahwa kriteria psikoterapi yang berhasil sangat bergantung pada tujuan yang ditentukan oleh subjek (Nematzadeh \& Sary, 2014). 
Alasan menggunakan terapi realitas adalah agar subjek dapat mengetahui kelebihan dan kekurangannya, dan subjek juga dapat memiliki rencana positif untuk dirinya sehingga subjek tidak lagi cemas dan putus asa dan diharapkan target intervensi dapat tercapai yaitu subjek memiliki penerimaan diri yang lebih baik lagi untuk masa depannya. Berikut tahapan dan proses reality therapy untuk subjek:

Sesi 1: Building Rapport dan kontrak kerja.Terapis membangun raport dan menumbuhkan kepercayaan pada subjek dan memberikan gambaran akan terapi yang dilakukan dengan membuat kesepakan serta informed consence, kegiatan ini bertujuan untuk memotivasi subjek agar bersedia mengikuti proses terapi hingga akhir sesi. Sesi ini subjek menyetujui dan kooperatif serta memiliki komitmen untuk berubah menjadi lebih baik lagi.

Sesi 2: Eksplorasi keinginan, kebutuhan dan persepsi (wants). Terapis meminta subjek untuk mengatakan apa keinginannya lalu kemudian menuliskannya di selembar kertas. Sama halnya dengan kelebihan dan kekurangnnya. Pada sesi ini dapat berjalan dengan baik walupun di awal subjek sempat kebingungan dengan apa kelebihan dan kekurangan dirinya. Subjek menyetujui menulis pada selembar kertas yang sudah disediakan agar subjek tidak lupa dan mengetahui dengan jelas apa yang dirinya inginkan baik untuk saat ini maupun di masa mendatang.

Sesi 3: Membuat penilaian (Doing). Terapis meminta subjek untuk membaca ulang apa kelebihan serta kekurangannya. Subjek diminta menganalisis bagaimana cara memaksimalkan kelebihannya dan meminimalisir kekurangannya agar tidak menghambat keinginannya. Dalam sesi ini, subjek mulai menyadari apa yang dirinya miliki dan menurut subjek dirinya mampu untuk melakukan hal tersebut.

Sesi 4: Menyusun rencana positif dan evaluasi (Evaluation). Setelah subjek memahami dengan baik kelebihan dan kekurangannya subjek bersama dengan terapis menganalisis keinginan subjek yang sudah subjek tuliskan dalam sesi sebelumnya. Subjek dan terapis bersama-sama membuat rencana positif agat keinginan subjek dapat terpenuhi tanpa kendala dengan cara memaksimalkan kemampuan dalam dirinya.

Sesi 5: Menyusun keinginan dan komitmen bersama (Plan). Subjek sudah memahami dan memiliki rencana untuk kedepannya baik dalam hal kuliah maupun dirinya sendiri. Terapis membantu subjek untuk membuat rencana bagaimana agar subjek selalu mengingat kelebihannya sebagai hal positif sehingga subjek dapat maksimal dalam menjalakan berbagai hal termasuk perkuliahan. Subjek juga diminta untuk menjalin hubungan sosial yang lebih baik dengan teman-temannya terlebih teman sekelas agar subjek mendapat dukungan

Sesi 6: Terminasi. Subjek diminta untuk menyimpulakan apa kelebihannya, kekurangan, dan keinginan serta bagaimana cara mewujudkannya. Terapis memotivasi subjek agar terus mengingat hal tersebut dan melakukannya agar subjek lebih dapat menerima dan mnegnal dirinya serta kemampuannya dengan baik.

Sesi 7: Follow up. Terapis melakukan wawancara pada subjek dan menanyakan tentang keadaan subjek dan bagaimana penerapan inetrvensi yang sudah dilakukan.

\section{Hasil dan Pembahasan}

\section{Hasil}

Dari intervensi yang telah dilakukan dapat dilihat bahwa terjadi peningkatan self acceptance pada subjek. hal ini ditandai dengan subjek yang sudah mulai mengetahui kelebihannya serta kekurangannya. Subjek juga telah membuat rencana yang baik bagi dirinya baik untuk jangka pendek maupun jangka panjang. Subjek sudah mulai mengoptimalkan kelebihannya dan mulai meminimalisir kekurangan yang dirinya miliki dan menjadikannya motivasi. Subjek juga merasa 
rasa cemasnya sedikit berkurang dan subjek mau berusaha belajar dengan maksimal sebelum presentasi atau ujian di kampusnya dan tidak akan mudah putus asa. Sebelumnya subjek mudah merasa putus asa dan tidak tahu akan kemampuannya sendiri.

Sebelum intervensi dimulai subjek pertama-tama diberikan skala penerimaan diri untuk mengukur sejauh mana subjek memiliki penerimaan diri positif dalam dirinya. Setelah subjek mengisi kemudian diperoleh skor rata-rata untuk penerimaan diri subjek yaitu sebesar 3,7 yang berarti cenderung rendah. Kemudian setelah intervensi dilakukan pada waktu follow up subjek diminta mengisi skala yang sama yang bertujuan untuk mengetahui peribahan pada subjek, setelah itu diperoleh skor penerimaan diri sebesar 5 yang berarti subjek sudah memiliki penerimaan diri positif yang cukup baik. Hal ini mennjukkan bahwa intervensi yang dilakukan telah memenuhi target yaitu meningkatkan penerimaan diri subjek. Perubahan yang terlihat setelah dilakukannya intervensi reality therapy dapat dilihat pada Tabel 1.

\section{Pembahasan}

Terapi realitas berlandaskan premis bahwa ada suatu kebutuhan psikologis tunggal yang hadir sepanjang hidup. Kebutuhan akan identitas menyebabkan adanya dinamika tingkah laku yang dipandang sebagai universal pada semua kebudayaan. Dalam pembentukan identitas, masingmasing dari kita mengembangkan keterlibatan orang lain untuk memainkan peranan yang berarti dalam membantu kita dalam menjelaskan dan memahami identitas kita sendiri (Corey, 2010). Flanagan \& Flanagan (2004) manusia termotivasi untuk memenuhi satu atau lebih dari lima kebutuhan dasar, baik secara genetis maupun kebutuhan lain. Lima kebutuhan dasar manusia tersebut adalah kelangsungan hidup, cinta dan rasa memiliki, kekuatan atau prestasi, kebebasan atau kemerdekaan, dan kesenangan. Dengan dilakukannya terapi tersebut subjek secara tidak langsung telah memperbaiki lima kebutuhan dasarnya yang belum terpenuhi dan menjadikan subjek sebagai individu yang lebih baik dengan dapat menerima dirinya sendiri.

Penerimaan diri diartikan sebagai penerimaan seseorang terhadap semua yang ada pada dirinya termasuk kekurangannya sendiri serta kelemahan-kelemahannya (Shepard \& Shepard, 2015). Subjek telah mampu untuk mencari tahu tentang kelebihan apa yang dirinya miliki dan bagaimana cara mengoptimalkan kelebihan tersebut agar keinginanya dapat tercapai. Selain itu subjek juga telah mengetahui kekurangan yang subjek miliki dan bagaimana harus bersikap sehingga subjek tidak putus asa dan selalu merasa tidak mampu. Subjek telah menunjukkan bahwa kekurangan akan subjek jadikan sebagai motivasi agar terus berjuang meraih cita-citanya yang sebenarnya.

Dengan reality therapy, terapis mencoba untuk menanamkan pada diri subjek bahwa apa yang telah subjek lakukan saat ini akan berdampak positif bagi subjek mapun orang di sekitarnya

Tabel 1. Hasil perkembangan subjek

\begin{tabular}{|c|c|}
\hline Sebelum intervensi & Setelah intervensi \\
\hline $\begin{array}{l}\text { Subjek belum memahami tentang dirinya terkait } \\
\text { kelebihan dan kekurangan yang subjek miliki }\end{array}$ & $\begin{array}{l}\text { Subjek telah mampu mengetahui dan } \\
\text { mengidentifikasi apa saja kelebihan dan } \\
\text { kekurangannya }\end{array}$ \\
\hline $\begin{array}{l}\text { Subjek belum memiliki rencana apapun untuk } \\
\text { dirinya baik untuk jangka pendek maupun } \\
\text { jangka panjang }\end{array}$ & $\begin{array}{l}\text { Subjek telah memiliki rencana positif untuk } \\
\text { dirinya }\end{array}$ \\
\hline $\begin{array}{l}\text { Subjek belum mampu untuk merealisasikan } \\
\text { keinginannya karena merasa tidak mampu }\end{array}$ & $\begin{array}{l}\text { Subjek sudah berani menentukan sikap } \\
\text { bagaimana dirinya nanti akan bertindak } \\
\text { untuk mewujudkan keinginannya dan tidak akan } \\
\text { putus asa serta menjadikan kekurangan sebagai } \\
\text { motivasi untuk lebih baik lagi }\end{array}$ \\
\hline
\end{tabular}


(Jahromi \& Mosallanejad, 2014). Subjek dapat memenuhi kebutuhan dasarnya yang belum terpenuhi dan subjek merasa hal tersebut akan baik bagi dirinya sehingga subjek tidak akan mudah menyerah dan putus asa selain itu kecemasan subjek juga akan sedikit menurun setelah intervensi ini dilakukan.

\section{Simpulan}

Reality therapy yang dilakukan kepada subjek berdampak positif. Subjek dapat mengetahui kelebiahn dan kekurangannya serta mampu membuat rencana positif untu dirinya. Subjek akan berusaha belajar dengan baik di jurusan ini agar dapat mewujudkan cita-citanya dan subjek juga tidak akan mudah putus asa dan mudah cemas lagi. subjek juga telah mengetahui bahwa kelemahan tidak boleh dijadikan hambatan namun harus dijadikan sebagai motivasi agar subjek terus maju. Subjek ingin membuat orang tuanya bangga akan dirinya dan oleh sebab itu subjek harus belajar dan bekerja keras. Berdasarkan asesmen dan intervensi yang telah dilakukan, terdapat beberapa rekomendasi dan saran sebagai berikut:

Saran yang dapat diberikan untuk subjek agar lebih mengoptimalkan kelebihan yang dimiki dan tidak mudah menyerah ketika ada permasalahan. Subjek juga diharapkan dapat mulai terbuka dengan teman-temannya sehingga subjek dapat memiliki dukungan. Bagi teman subjek yaitu diharapkan dapat memberikan dukungan pada subjek dan tidak meninggalkan subjek jika subjek terlihat murung. Sesekali ajak subjek berbicara dari hati ke hati agar subjek mau terbuka dan menerima bantuan dari temannya. Praktikan atau psikolog selanjutnya diharapkan untuk psikolog selanjutnya ang menangani subjek dapat membantu memperbaiki hubungan antara ayah dan subjek melalui konseling keluarga, agar subjek dan ayahnya dapat memahami satu sama lain. Selain itu dapat membantu menangani permasalahan kecemasan yang dihadapi subjek dengan terapi CBT atau terapi lain yang sesuai.

\section{Referensi}

APA. (2013). Diagnostic and statistical manual of mental disorders (5th Ed.). Washington DC and London: American Psychiatric Association.

Carson, S. H., \& Langer, E. J. (2014). Mindfulness and self-acceptance. Journal of RationalEmotive and Cognitive-Behavior Therapy, 24(1), DOI: 10.1007/s10942-006-0022-5.

Corey, G. (2009). Theory and practice of counceling and psychotherapy (8th Ed.). USA: Thomson Brooks/Cole.

Ellswort, L. (2007). Chosing to heal using reality therapy in the treatment of sexually abuse children. New York, London: Routledge.

Farahanifar, M. (2016). The effect of group consulting based on reality therapy on self-control and resiliency of women having disabled children of arak city. International Journal Of Humanities And Cultural Studies, (2016), 2217-2227.

Flanagan, J. S., \& Flanagan, R. S. (2004). Counseling and psychotherapy theories in context and practice skills, streategies, and techniques. Canada: John Wiley Sons, Inc.

Glasser, W. (2005). Warning: Psychiatry can be hazardous to your mental health. Journal of Clinical Psychiatry, 7(244). https://doi.org/10.4088/PCC.v07n0208

Jahromi, M. K., \& Mosallanejad, L. (2014). The impact of reality therapy on metacognition, stress and hope in addicts. Iranian journal of educational Sociology, 1(6), 76-84.

Nematzadeh, A., \& Sary, H. S. (2014). Effectiveness of group reality therapy in increasing the teachers' happiness. Procedia-Social and Behavioral Sciences, 116(2016), 907-912. https://doi.org/10.1016/j.sbspro.2014.01.318

Nutt, D., Griez, E. J. L., Faravelli, C., Zohar, J., \& Wiley, J. (2001). Anxiety disorders. New York: Tottenham Court Road.

Shepard, L. A., \& Shepard, L. A. (2015). Self-acceptance : The evaluative momponent of the self-concept construct. American Educational Research Journal, 16(2), 139-160.

Vasile, C. (2013). An evaluation of self-acceptance in adults. Procedia-Social and Behavioral Sciences, 78, 605-609. https://doi.org/10.1016/j.sbspro.2013.04.360

Wubbolding, R. E. (2017). Reality therapy and self-evaluation: The key to client change (K. Mikel, ed.). Alexandria: American Counseling Association.

Yao, Y. W., Chen, P. R., Li, C. shan R., Hare, T. A., Li, S., Zhang, J. T., .. Fang, X. Y. (2017). Combined reality therapy and mindfulness meditation decrease intertemporal decisional impulsivity 
in young adults with Internet gaming disorder. Computers in Human Behavior, 68, 210-216. https://doi.org/10.1016/j.chb.2016.11.038

Younesi, S. J., Khazan, K., Jani, S., \& Mahdizadeh, Z. (2017). The effectiveness of reality therapy concepts on self-esteem of the elderly in the center of aramesh in parsabad. Journal of Advances in Medical and Pharmaceutical Sciences, 12(1), 1-8. 